Ethos: Jurnal Penelitian dan Pengabdian Masyarakat, Vol 8, No.2, Juni 2020:171-178

\title{
Program KemitraAn MASyarakat Industri KeripiK Tempe DeSa BaKalan KRAJAN KECAMATAN SUKUN
}

\author{
${ }^{1}$ Dana Marsetiya Utama, ${ }^{2}$ Teguh Baroto \\ 1,2Teknik Industri, Fakultas Teknik, Universitas Muhammadiyah Malang, Jalan Raya Tlogomas 246 \\ Malang, 0341-464318, \\ email: ' dana@umm.ac.id, ${ }^{2}$ teguh@umm.ac.id
}

\begin{abstract}
Indonesian community are known as a community that likes to consume Tempe. Tempe chips are one of the special food from Malang. Community partnership Activities (PKM) are carried out in Bakalankrajan of sukun in Malang. The partners of Community Partnership Activities (PKM) is "Londho" Tempe chips. Problems that must be resolved immediately include: 1) increasing the quality and production capacity that is more effective and efficient production, especially in the packaging process. 2) Improving the management production of marketing properly to increase the sales of Tempe chips. The Implementation method of PKM is through the participatory Rural Apprasial (PRA). The result of continuous sealer appropriate technology (TTG) assistance shows that there is an increase of Tempe chips production. The result of marketing management training shows that there is an increase in business marketing management knowledge. Furthermore, the result of marketing management training can increase product sales turnover.
\end{abstract}

Keywords: PKM, Chips, Marketing, TTG.

\begin{abstract}
Abstrak. Masyarakat Indonesia dikenal dengan masyarakat yang gemar mengonsumsi tempe. Keripik tempe merupakan salah satu makanan dan oleh-oleh khas Kota Malang. Kegiatan Program Kemitraan Masyarakat (PKM) dilaksanakan di Kelurahan Bakalankrajan Kecamatan Sukun Kota Malang. Mitra di kegiatan PKM ini adalah keripik tempe "Londho". Masalah yang harus diselesaikan segera diantaranya 1). peningkatkan kualitas dan kapasitas produksi yang lebih efektif dan efisien khususnya pada proses pengemasan. 2). Peningkatan pengelolaan manajemen pemasaran dengan baik sehingga dapat meningkatkan penjualan keripik tempe. Metode pelaksanaan kegiatan PKM ini melalui Participatory Rural Apprasial (PRA). Hasil bantuan teknologi tepat guna (TTG) continious sealer menunjukan terdapat peningkatan produksi keripik tempe. Hasil pelatihan manajemen pemasaran menunjukan terdapat peningkatan pengetahuan manajemen pemasaran usaha. Lebih lanjut, hasil pelatihan manajemen pemasaran dapat meningkatkan omzet penjualan produk.
\end{abstract}

Kata Kunci: PKM, Keripik, Pemasaran, TTG.

\section{Pendahuluan}

Masyarakat Indonesia dikenal dengan masyarakat yang gemar mengonsumsi tempe. Tempe menjadi makanan yang disajikan setiap hari. Tempe memiliki kandungan protein tinggi (Shurtleff \& Aoyagi, 1979). Tempe merupakan makanan dari bahan baku utama kacang kedelai (Utama \& Baroto, 2018). Kandungan protein nabati yang baik menjadikan Kacang kedelai memiliki protein yang tinggi (Ginting, Antarlina, \& Widowati, 2009). Untuk menghasilkan tempe, kacang kedelai berfermentasi dengan jamur rhizopus oligosporus (Haliza, Purwani, \& Thahir, 2016). Karena itu, fermentasi 
menghasilkan Padatan putih. warna putih pada tempe disebabkan miselia jamur yang tumbuh pada permukaan biji kedelai (Halifah, 2011). Kandungan Gizi pada tempe seperti karbohidrat, vitamin, serat, lemak, dan mineral (Utari, 2010).

Di kota malang, tempe diolah menjadi keripik tempe. Keripik tempe merupakan salah satu makanan khas dan oleh-oleh khas pada wisatawan saat liburan di Malang. Kandungan vitamin C dan kadar lemak $7.48 \%$ AKG per 100 gram pada Keripik tempe menjadikan makanan ini sangat diminati oleh wisatawan (Yuniarti, Azlia, \& Sari, 2015). Dikota malam, Produk keripik tempe dihasilkan oleh Usaha Kecil Menengah (UKM). UKM di Kota Malang memiliki peranan besar dalam perekonomian dan wisata (Yusriansyah, 2012).

Home industry keripik tempe "Londho" didirikan oleh Ibu Sri Wahyuningsih. Home industry keripik tempe "Londho" memulai usaha produksi tempe sejak tahun 1992. Home industry keripik tempe "Londho" beralamatkan di RT 05 RW 04 Kelurahan Bakalankrajan. Home industry keripik tempe "Londho" mempunyai 6 orang tenaga kerja. Home industry keripik tempe "Londho" mampu memproduksi sebanyak $25 \mathrm{~kg}$ tiap hari. Home Industry "Londho" menjual produk kiripik di toko oleholeh dan masyarakat sekitar. Penjualan keripik tempe dalam satu minggu produk keripik tempe home industry tempe "Londho" relatif fluktuatif. Omzet penjualan per minggunya mencapai Rp 9 juta.

Pada aspek produksi keripik tempe, secara umum home Industry "Londho" memiliki beberapa tahap. Tahap 1 adalah proses pemotongan tempe sesuai ukuran. Tahap 2 pencampuran adonan dan penggorengan keripik. Tahap 3 melakukan penirisan.
Tahap 4 (terakhir) melakukan pengemasan. Pada aspek manajemem pemasaranya, home Industry "Londho" masih mengandalkan proses pemasaran dari mulut ke mulut dan menitipkan produk keripik tempe ke toko oleh-oleh. Produk keripik tempe kurang diminati disebabkan produk keripik tempe mudah berasa tidak sedap (tengik). Selain itu, kemasan produk keripik tempe yang banyak lubang karena menggunakan lilin untuk pengemasan. Pada aspek harga, harga jual produk relatif lebih mahal dari pada pesaing karena produk tidak menggunakan bahan pengawet. Meskipun usaha ini masih bersifat mikro, namun pemilik usaha ini tetap optimis dalam menjalankan usahanya terbukti dengan keinginan kuat untuk mengembangkan usaha dengan meningkatkan kualitas produk keripik tempe, memperbaiki proses pengolahan, memperbaiki manajemen usaha dan memperluas pemasaran produk.

Kualitas rasa produk keripik tempe kedelai mitra sanggup bersaing dengan industri tempe yang lain. Namun, mitra belum berani untuk menambah kapasitas produksi keripik tempe. Hal ini disebabkan proses produksi yang digunakan oleh mitra masih sangat sederhana. Produk tempe yang dibuat masih menggunakan metode pengolahan yang manual. Pada proses pemotongan tempe, mitra sudah memiliki alat potong tempe dengan kapasitas potong $10 \mathrm{~kg}$ dalam 1 jam. Proses penggorengan keripik tempe menggunakan alat gorenng manual. Proses penggorengan keripik tempe membutuhkan 2 tahapan. Penggorengan tahap 1 membutuhkan api sedang dengan waktu 3 menit. Selanjutnya, penggorengan dilanjutkan dengan menggunakan api besar dengan waktu 2 menit. Kapasitas alat penggorengan mitra sebesar $1 \mathrm{~kg}$ tiap 1 kali penggorengan. Setelah proses 
penggorengan, langkah selanjutnya adalah penirisan. Pada proses penirisan ini, mitra membutuhkan waktu 1 jam untuk melakukan penirisan. Penirisan dilakukan secara tradisional dengan menggukanan tempat traditional (nampan). Oleh karena itu, keripik tempe yang diproduksi tidak bisa sepenuhnya tiris dari minya goreng. Sehingga produk yang dihasilkan sering memiliki rasa bau tidak sedap. Selain itu, proses pengemasan masih dilakukan dengan cara yang sangat tradisional. Mitra menggunakan media lilin untuk membantu proses pengemasan. Pada tahap pengemasan ini, produk dikemas dengan ukuran 100 gr. Proses pengemasan ini menimbulkan kualitas produk yang tidak dapat bertahan lama.

Umumnya permasalahan UKM adalah dibidang kualitas (Utama \& Baroto, 2018), pengendalian persediaan (Maulana et al., 2019; Utama, 2017a, 2017b, 2019b, 2019c; Utama, Wardani, Halifah, \& Pradikta, 2019), penjadwalan produksi (Utama, 2018a, 2018b, 2019a; Utama, Ardiansyah, \& Garside, 2019; Utama, Baroto, Maharani, Jannah, \& Octaria, 2019; Utama, Garside, \& Wicaksono, 2019; Utama, Widodo, Wicaksono, \& Ardiansyah, 2019), dan sistem informasi (Garside \& Utama, 2017; Utama \& Yulianto, 2014). Namun, berdasarkan prioritas permasalahan yang telah disepakati antara mitra dan tim PKM terdapat masalah yang harus diselesaikan segera diantaranya 1). Bagaimana home industri meningkatkan kualitas produksi dengan proses produksi yang lebih efektif dan efisien khususnya pada proses pengemasan. 2). Bagaimana home indstry dapat mengelola manajemen pemasaran dengan baik sehingga dapat meningkatkan penjualan keripik tempe. Solusi yang di tawarkan program PKM ini adalah memberikan bantuan tenologi tepat guna pengemasan serta pelatihan dan pendampingan tahapan pengemasan untuk meningkatkan kualitas. Lebih lanjut, PKM ini juga melakukan Pelatihan manajemen pemasaran bertujuan agar mitra memahami manajemen pemasaran yang baik.

\section{Metode}

Metode kegiatan Program Kemitraan Masyarakat (PKM) adalah dengan Focus Group Discussion (FGD) dan metode Participatory Rural Apprasial (PRA). Focus Group Discussion (FGD) dilakukan untuk mengidentifikasi permasalahan mitra, menetapkan prioritas masalah, dan memberikan usulan pemecahan masalah yang tepat bagi mitra. Sedangkan metode Participatory Rural Apprasial (PRA) yaitu melibatkan mitra untuk turut serta dalam pelaksanaan kegiatan. Kegiatan PKM ini dilakukan melalui penyuluhan, pelatihan dan pendampingan serta evaluasi untuk melihat efektifitas program.

Bantuan teknologi alat continious sealer dapat meningkatkan produksi dan kualitas keripik tempe. Penelitian terdahulu yang terkait dengan desain alat contonious sealer dilakukan oleh Wahyudi and Uslianti (Wahyudi \& Uslianti, 2016) dan Dunas (2012) . Selain itu beberapa penelitian tentang efek penggunaan alat contonious sealer seperti Jamaludin and Setyawan (2016) dan Mubarok (2019) . Penelitian tersebut menyimpulkan bahwa penggunaan alat contonious sealer dapat menjaga kualitas makanan.

Solusi Pelatihan dan pendampingan manajemen pemasaran usaha dipilih agar usaha industri keripik tempe menerapkan manajemen pemasaran yang baik. Dalam pelatihan dan pendampingan manajemen pemasaran, tim pengabdian menggunakan acuan beberapa literatur buku yang membahas mengenai manajemen pemasaran usaha kecil 
diantaranya Kotler, Saliba, and Wrenn (1991), Assauri (1987), dan Arnould, Price, and Zinkhan (2002). Kegiatan penyuluhan dan pelatihan ini dilakukan 2 kali pertemuan. Kegiatan Pendampingan manajemen pemasaran mitra selama 2 bulan dengan memberikan konsultasi. Selain itu, tim pengabdian melakukan kunjungan secara periodik.

Metode Participatory Rural Apprasial (PRA) adalah melibatkan mitra untuk mengikuti semua kegiatan pelatihan dan peyuluhan serta pendampingan oleh tim PKM. Tim PKM juga memberikan pendampingan kepada mitra mitra untuk untuk mengimplementasikan hasil kegiatan.

Selanjutnya pengendalian PKM dilakukan melalui kegiatan monitoring, pengawasan, evaluasi, pelaporan dan tindak lanjut terhadap pelaksanaan kegiatan. Pengendalian digunakan untuk memastikan seluruh tahapan kegiatan sesuai dengan program yang telah ditetapkan dan solusi yang ditawarkan ke mitra. Selain itu, Mengendalikan kegiatan agar sesuai dengan program yang telah ditetapkan. Menjaga kualitas kegiatan sehingga dapat memenuhi indikator keberhasilan program yang diamati secara langsung dari output (luaran) yang telah diuraikan sebelumnya.

\section{Hasil dan Pembahasan}

\subsection{Pemberian Bantuan Fisik Berupa Mesin}

Serah terima program diseminasi teknologi ke masyarakat dan untuk dapat mengimplementasikan barang/peralatan berupa : "Alat continous sealer" yang diperoleh dari kegiatan Diseminasi Produk Teknologi ke Masyarakatdan kepada mitra. Serah terima serah terima alat ke kedua mitra. Serah terima telah dilakukan pada tanggal 14 Agustus 2019 pada pukul 10:00. Penyerahan dilakukan di rumah pemilik. Serah terima alat ini bertujuan agar mitra dapat meningkatkan volume produksi. Dokumentsi serah terima alat dapat dilihat pada gambar 1 .

\subsection{Pelatihan Manajemen pemasaran}

Pelatihan manajemen pemasaran usaha dilaksanakan pada hari Sabtu, tanggal 27 Juli 2019 jam 08.00 - 12.00 bertempat di home industri keripik londho. Pelatihan yang dihadiri oleh 8 peserta. Peserta ini terdiri dari 2 orang yang berasal dari tim pengabdian dan 6 peserta berasal dari industri tempe. Pelatihan dimulai dengan penyampaian materi oleh Dana Marsetiya Utama, ST., MT dan selanjutnya tanya jawab (gambar 2). Pada kesempatan tersebut ada 2 materi yang disampaikan yaitu: 1) Marketing Mix, dan 2) Strategi penjualan. Setiap peserta diberikan handout "manajemen pemasaran usaha" dengan harapan peserta dapat memahami dan menerapkan materi yang telah disampaikan.

Evaluasi keberhasilan pelatihan dilakukan dengan uji pengetahuan dan uji keterampilan. Uji dilakukan untuk menganalisis signifikansi perubahan pengetahuan sebelum dan sesudah pelatihan. Keterampilan yang berkaitan dengan 1) Marketing Mix, dan 2) Strategi penjualan. Ceklis keterampilan digunakan sebagai pedoman penilaian. Setelah pelatihan usai kemudian dilakukan uji keterampilan melakukan pemahaman 1) Marketing Mix, dan 2) Strategi penjualan. Pengetahuan peserta pelatihan meningkat secara signifikan $(\mathrm{p}=0,012)$. Hal itu dapat dilihat dari perubahan nilai rata-rata ketika menjawab soal 1) Marketing Mix, dan 2) Strategi penjualan. Berikut hasil uji (Tabel 1) tersebut. Hasil pemberian bantuan fisik berupa mesin dapat meningkatkan kapasitas produksi mitra. Data produksi dalam 1 minggu dapat dilihat pada gambar 3. Hasil ini menunjukan bahwa teknologi tepat guna 
dapat meningkatkan kapasitas produksi usaha. Hasil ini sesuai dengan hasil pengabdian yang telah dilakukan oleh Utama (2019e), dan Munaf, Suseno, Janu, and Badar (2008). Lebih lanjut, Hasil pelatihan manajemen pemasaran dapat meningkatkan omzet penjualan mitra. Data omzet penjualan dalam 1 minggu dapat dilihat pada gambar 4 .

Tabel 1. Hasil Uji Wilcoxon Pengetahuan manajemen pemasaran peserta pelatihan

\begin{tabular}{lcrrrr}
\hline Pengetahuan & N & Mean & $\begin{array}{c}\text { Std. } \\
\text { Deviation }\end{array}$ & Z & \multicolumn{1}{c}{$\begin{array}{c}\text { Asymp. Sig. } \\
\text { (2-tailed) }\end{array}$} \\
\hline Sebelum & 6 & 14,1250 & 1,64208 & $-2,527^{\mathrm{b}}$ & 0,012 \\
Sesudah & 6 & 21,1250 & 1,12599 & & \\
\hline
\end{tabular}
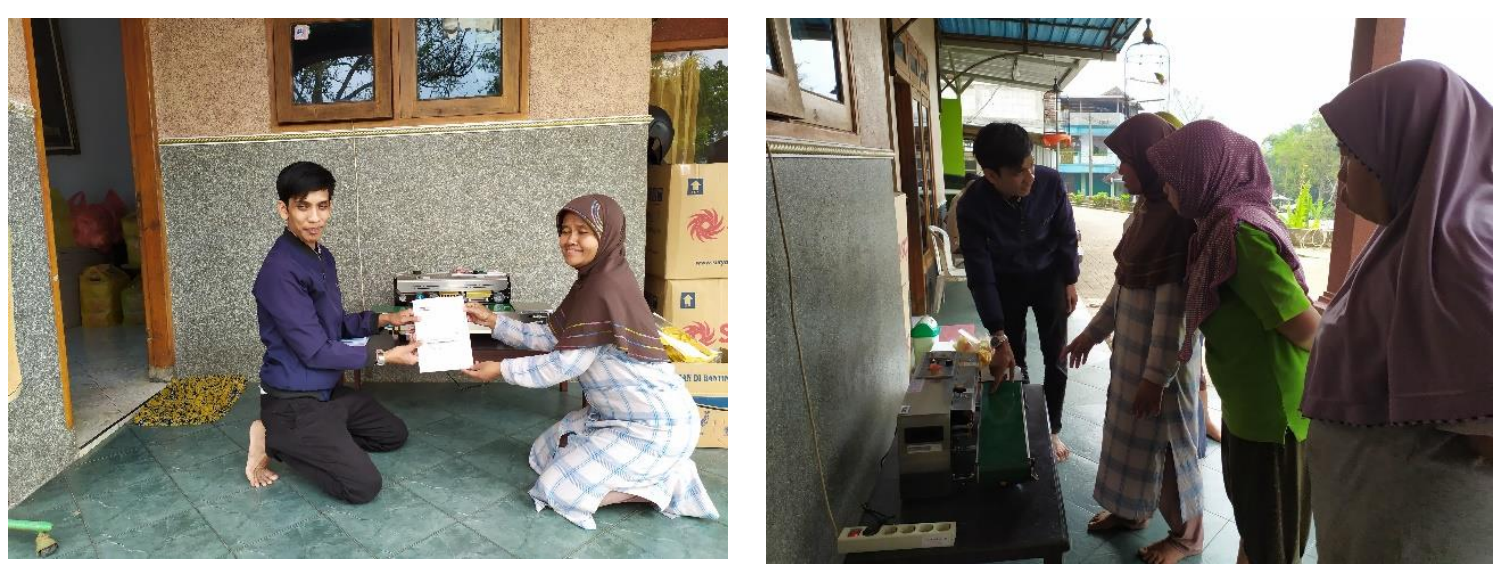

Gambar 1. Penyerahan alah dan Pelatihan penggunaan alat continepus sealer oleh Dana Marsetiya Utama, ST., MT
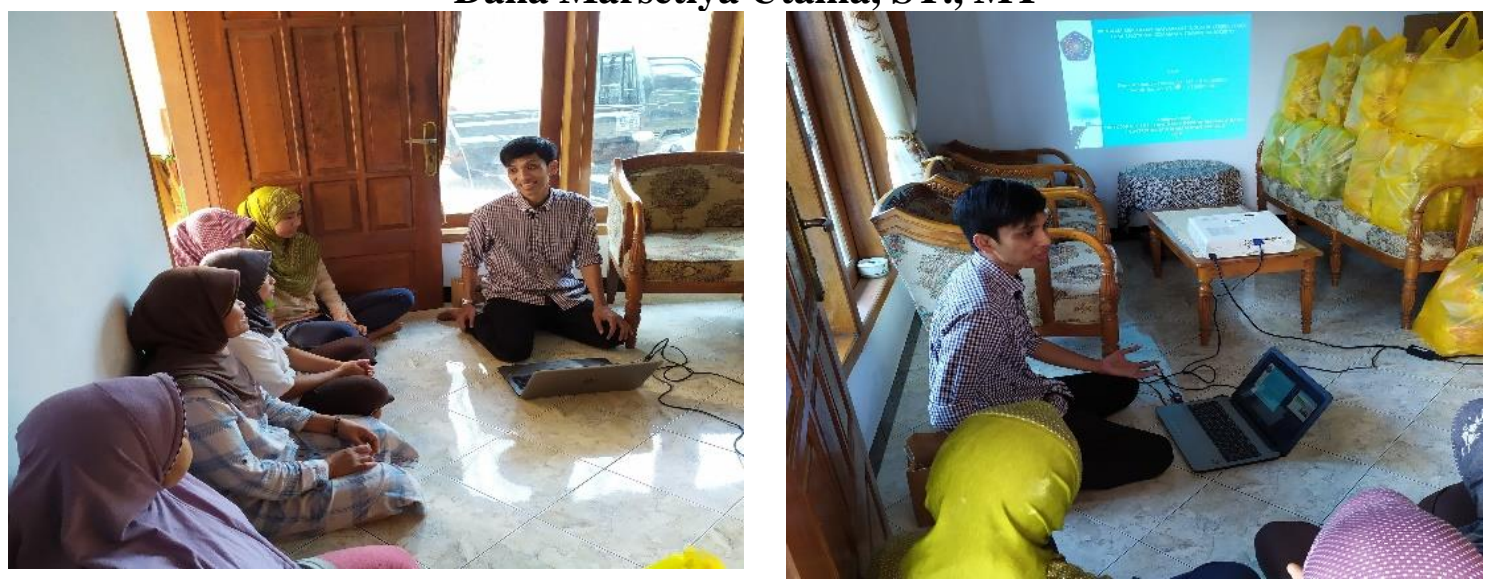

Gambar 2. Pelatihan manajemen pemasaran usaha oleh Dana Marsetiya Utama, ST., MT 
Dana Marsetiya Utama, et al.

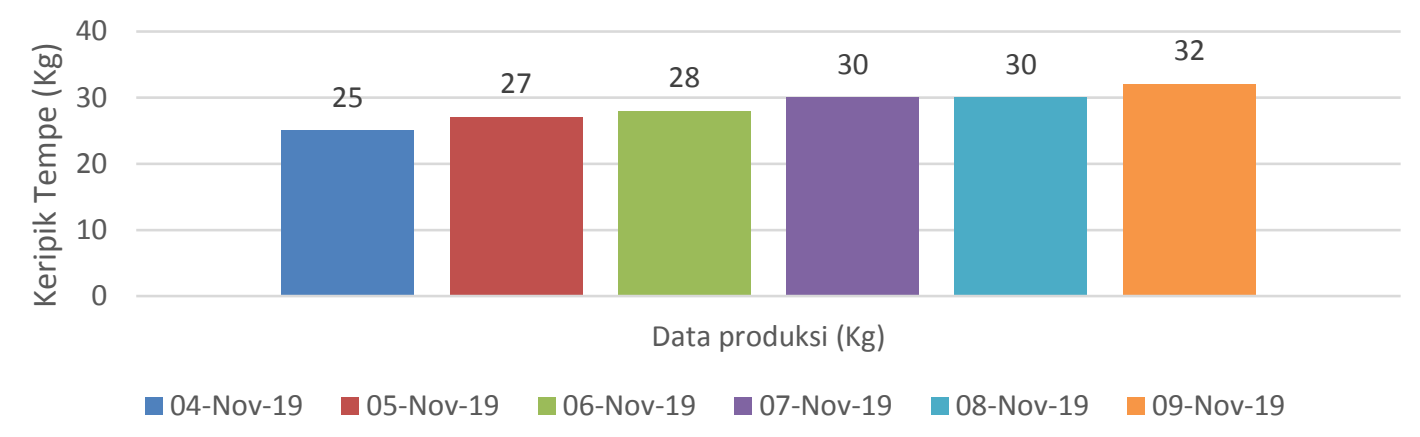

Gambar 3. Data produksi setelah bantuan teknolgi tepat guna

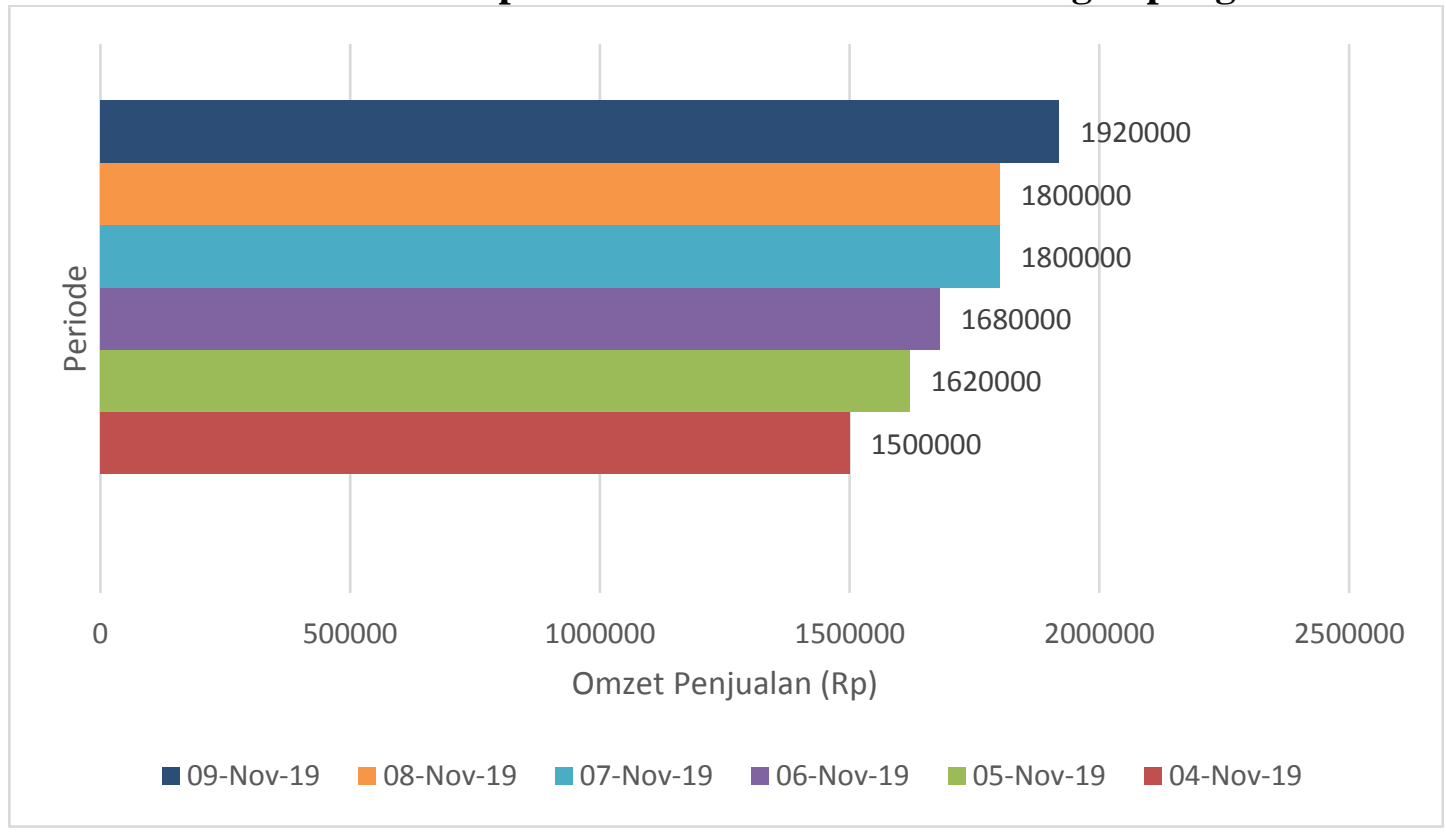

Gambar 4. Omzet Penjualan setelah pendampingan manajemen pemasaran

\section{Kesimpulan dan Saran}

Dari kegiatan yang sudah dilakukan menunjukan bahwa kegiatan pengabdian dapat memberikan dampak yang cukup signifikan kepada mitra. Namun, tim PKM perlu melakukan kegiatan lebih lanjut untuk memastikan mitra dapat memperbaiki kegiatan produksi dan manajemen.

\section{Ucapan Terima Kasih}

Ucapan terimakasih kepada Universitas Muhammadiyah Malang yang memberikan dukungan dalam pelaksanaan Program Kemitraan Masyarakat..

\section{DAFTAR PUSTAKA}

Arnould, E. J., Price, L., \& Zinkhan, G. M. (2002). Consumers: McGrawHill/Irwin.

Assauri, S. (1987). Manajemen pemasaran: dasar, konsep den strategi: CV Rajawali.

Dunas, B. B. R. (2012). Mesin Continuous Band Sealer dengan Suhu Pemanas Yang dapat Dirubah Dilengkapi Konveyor Berbasis Kendali Elektromekanik. SKRIPSI Jurusan Teknik Elektro-Fakultas Teknik UM.

Garside, A. K., \& Utama, D. M. (2017). Perancangan Sistem Informasi Laboratorium Teknik Industri 
Universitas Muhammadiyah Malang. Research Report, 1(1).

Ginting, E., Antarlina, S. S., \& Widowati, S. (2009). Varietas unggul kedelai untuk bahan baku industri pangan. Jurnal Litbang Pertanian, 28(3), 79-87.

Halifah, P. (2011). Pengaruh lama perebusan terhadap kadar protein tempe kacang tunggak (Vigna unguiculata). bionature, 12(1).

Haliza, W., Purwani, E. Y., \& Thahir, R. (2016). Pemanfaatan kacangkacangan lokal sebagai substitusi bahan baku tempe dan tahu. Buletin Teknologi Pasca Panen, 3(1), 1-8.

Hamdan, Y., Ratnasari, A., Sofyan, A., \& Tandika, D. (2017). Promosi Bisnis Untuk Meningkatkan Omzet Penjualan. InterKomunika, 2(2), 108-113.

Jamaludin, M., \& Setyawan, H. (2016). Mesin Filling Dan Cup Sealer Tenaga Pneumatik Untuk Segala Minuman Dalam Cup. Tugas Akhir Jurusan Teknik Mesin-Fakultas Teknik UM.

Kotler, P., Saliba, S., \& Wrenn, B. (1991). Marketing management: Analysis, planning, and control: Instructor's Manual: Prentice-hall.

Maulana, S. K. D. B., Utama, D. M., Asrofi, M. S., Ningrum, I. S., Alba, N., Ahfa, H. A., \& Zein, T. A. ( 2019). The Capacitated Sustainable EOQ Model: A Model Considering Emission Tax. Jurnal Teknik Industri, 21(1), Article In Press.

Mubarok, M. H. (2019). Rancang bangun sistem otomatisasi mesin sealer box pada proses pengepakan box rokok di pt. djarum. UMK.

Munaf, D. R., Suseno, T., Janu, R. I., \& Badar, A. M. (2008). Peran Teknologi Tepat Guna untuk Masyarakat Daerah Perbatasan Kasus Propinsi Kepulauan Riau. Jurnal Sosioteknologi, 7(13), 329333.
Shurtleff, W., \& Aoyagi, A. (1979). A. Super Soy Food from Indonesia. Book of Tempeh. Harper and Row New York.

Sukarsih, I., Kurniati, E., Gunawan, G., \& Wulan, R. (2016). Perluasan Jangkauan Pasar Pelaku Ukm Sepatu Cibaduyut Melalui Pelatihan Dan Pendampingan Internet Marketing. ETHOS: Jurnal Penelitian dan Pengabdian, 1-6.

Sukarsih, I., Kurniati, E., Gunawan, G., \& Wulan, R. (2019). Perluasan Jangkauan Pasar Pelaku UMKM Di Kota Bandung melalui Implementasi E-Commerce. ETHOS: Jurnal Penelitian dan Pengabdian kepada Masyarakat, 7(2), 170-177.

Utama, D. M. (2017a). Model Penentuan Lot Pemesanan Dengan Mempertimbangkan Unit Diskon dan Batasan Kapasitas Gudang dengan Program Dinamis. Jurnal Teknik Industri, 18(1), 9.

Utama, D. M. (2017b). Model Program Dinamis Dalam Penentuan Lot Pemesanan dengan Mempertimbangkan Batasan Modal. Paper presented at the Prosiding SENTRA (Seminar Teknologi dan Rekayasa).

Utama, D. M. (2018a). Algoritma LPTBranch and Bound Pada Penjadwalan Flexible Flowshop untuk Meminimasi Makespan. PROZIMA (Productivity, Optimization and Manufacturing System Engineering), 2(1), 20-26.

Utama, D. M. (2018b). Pengembangan Algoritma NEH Dan CDS Untuk Meminimasi Consumption Energy Pada Penjadwalan Flow Shop. Prosiding SENTRA (Seminar Teknologi dan Rekayasa), 4, 47-54.

Utama, D. M. (2019a). An Effective Hybrid Sine Cosine Algorithm to Minimize Carbon Emission on Flow-shop Scheduling Sequence 
Dependent Setup. 2019, 20(1), 6272.

Utama, D. M. (2019b). Model Program Dinamis Untuk Lot Size Multi Item Dengan Kendala Kapasitas Gudang. J@ ti Undip: Jurnal Teknik Industri, 14(1), 21-26.

Utama, D. M. (2019c). Model program dinamis untuk lot size multi item dengan kendala kapasitas gudang. 2019, 14(1), 21-26.

Utama, D. M. (2019d). Penguatan Aspek Manajemen Produksi dan Kualitas Tempe Pada UKM Tempe. JPPM (Jurnal Pengabdian dan Pemberdayaan Masyarakat), 3(1), 133-140.

Utama, D. M. (2019e). PKM Industri Tempe Kelurahan Bakalankrajan Kecamatan Sukun Kota Malang. Paper presented at the Seminar Nasional Unisla 2018, Lamongan.

Utama, D. M., Ardiansyah, L. R., \& Garside, A. K. (2019). Penjadwalan Flow Shop untuk Meminimasi Total Tardiness Menggunakan Algoritma Cross Entropy-Algoritma Genetika. Jurnal Optimasi Sistem Industri, 18(2), 133-141.

Utama, D. M., \& Baroto, T. (2018). Penggunaan SAW untuk analisis proses perebusan kedelai dalam produksi tempe. Agrointek: Jurnal Teknologi Industri Pertanian, 12(2), 90-98.

Utama, D. M., Baroto, T., Maharani, D., Jannah, F. R., \& Octaria, R. A. (2019). Algoritma ant-lion optimizer untuk meminimasi emisi karbon pada penjadwalan flow shop dependent sequence set-up. 2019, 9(1), 69-78.

Utama, D. M., Garside, A. K., \& Wicaksono, W. (2019). Pengembangan algoritma Hybrid Flow shop Three-Stage Dengan Mempertimbangkan Waktu Setup. Jurnal Ilmiah Teknik Industri, 18(1), 72-78.
Utama, D. M., Wardani, D. P., Halifah, S. T., \& Pradikta, D. C. (2019). Model Economic Production Quantity dengan Rework Process dan Batasan Gudang. Jurnal Sistem dan Manajemen Industri, 3(1), 4349.

Utama, D. M., Widodo, D. S., Wicaksono, W., \& Ardiansyah, L. R. (2019). A New Hybrid Metaheuristics Algorithm for Minimizing Energy Consumption in the Flow Shop Scheduling Problem. International Journal of Technology, 10(2), 320-331.

Utama, D. M., \& Yulianto, F. (2014). Perancangan Sistem Enterprise Resource Planning Modul Sales Pada Distributor Beras Ud Manis. Jurnal Teknik Industri, 15(1), 61-69.

Utari, D. M. (2010). Kandungan Asam Lemak, Zink, Dan Copper Pada Tempe, Bagaimana Potensinya Untuk Mencegah Penyakit Degeneratif? Gizi Indonesia, 33(2).

Wahyudi, T., \& Uslianti, S. (2016). Peningkatan Kualitas dan Kuantitas Nugget Lele dengan Menggunakan Mesin Mekanis. ELKHA, 8(2), 1417.

Yuniarti, R., Azlia, W., \& Sari, R. A. (2015). Penerapan sistem Hazard Analysis Critical Control Point (HACCP) pada proses pembuatan keripik tempe. Jurnal Ilmiah Teknik Industri, 14(1), 86-95.

Yusriansyah, M. (2012). Karakteristik Pengusaha Industri Keripik Tempe Berbasis Produk Unggulan Di Kota Malang. Fakultas Ilmu Sosial Universitas Negeri Malang (UM). 